Volume 16, Number 5

September- 2015

\title{
Developing a Sustainable Financial Model in Higher Education for Open Educational Resources
}

David Annand

Athabasca University

\begin{abstract}
Financial issues regarding the sustainable production, dissemination, and use of Open Educational Resources (OER) in higher education are reviewed and proposed solutions critiqued. Use of OER produce demonstrable cost savings for students. Yet OER development continues to rely almost completely on government and philanthropic funding. This indicates that a mismatch exists between the financial interests of students and those of higher education institutions. Before OER will be broadly adopted, changes to government policy are required to align institutional objectives with faculty motivations and student needs.
\end{abstract}

Keywords: Open educational resources; economics of OER; disruptive innovation.

\section{Introduction}

The growing use of Open Educational Resources (OER) as a means to freely share, adapt, and propagate knowledge in formal and non-formal settings is one of OERthe more remarkable educational developments in the 21st century. The communiqué from the 2014 ICDE - UNESCO policy forum stated that access to open, online and flexible learning is a key to overcoming development challenges and learning needs of all societies in the current century. Use of OER was listed as one of the six critical means to accomplish this.

The Paris OER declaration (UNESCO, 2012) stated that “ . . . the term Open Educational Resources designates teaching, learning and research materials in any medium, digital or 
otherwise, that reside in the public domain or have been released under an open license that permits no-cost access, use, adaptation and redistribution by others with no or limited restrictions" (p. 1). In addition to learning content, two other components are necessary to produce effective open educational resources: the technological means to support the development, adaptation, and distribution of the learning content, and "implementation tools" the legal and regulatory framework that permits varying degrees of control over content (CERI, 2007, pp. 31-32). Chief among these tools is the rapidly-growing use of open licensing systems like Creative Commons (CC).

Butcher (2011) highlighted important differences between the nature of OER and related concepts. First, OER are not synonymous with open learning. The latter assumes not only the use of OER as instructional material, but also the ". . . systematic analysis of assessment and accreditation systems, student support, curriculum frameworks, mechanisms to recognize prior learning, and so on, in order to determine the extent to which they enhance or impede openness" (p. 6). Second, Butcher suggested that OER are not the same as resource-based learning. The latter subsumes OER, and is enabled by new technology that allows use of different media. Resource-based learning often results in a move away from predominantly face-to-face knowledge transmission models like lectures. Third, OER differ from open publishing. Open publishing refers to free access to mainly scholarly publications and research. OER specifically refer to teaching and learning materials, though scholarly articles can be incorporated for pedagogic purposes. Lastly, though OER can be an integral part of online learning, the concepts are different. OER are generally available in both print and electronic media, and can be utilized in a wider variety of educational settings.

The following discussion further assumes that OER are used in a formal higher learning environment. Within this context, primarily financial aspects of sustainable OER production, distribution, and use are examined.

\section{Obstacles to the Adoption of OER}

Some important non-financial issues prevent broader acceptance of OER. Bossu and Tynan (2011), and Sclater (2010) noted that in most contexts, there is academic concern over the perceived risks of OER adoption. These include reservations about quality, loss of control over intellectual property, threats to reputation (e.g. some mistakes will be permanently on view, outdated material will remain in circulation), and a reluctance as Plotkin (2010) noted, to surrender the 'crown jewels' of acquired faculty knowledge within an institution. The Babson report - a survey of over 2,100 US teaching faculty conducted by Allen and Seaman (2014) - also reported that the most significant barrier to more widespread adoption of OER by faculty was the perception that too much time and effort was required to locate and evaluate the material. Okonkwo (2012) and Armellini and Nie (2013) found that, though teaching faculty are willing to use OER, lack of technical skills limits their abilities to adapt and use OER. Though Mtebe and

This work is licensed under a Creative Commons Attribution 4.0 International License. 
Raisamo (2014) suggested that these barriers may not be equally applicable even in one geographic region like Africa, they nonetheless exist in all jurisdictions to some degree.

On the other hand, there are compelling financial arguments for the production and use of OER. Butcher and Hoosen (2012) suggested that since education is largely supported by public funds, all learning resources should be openly licensed. Even in jurisdictions where students must pay for their educational materials, OER proponents argue that the state pays less overall when students can use freely-available instructional material instead of purchased textbooks. Lower textbook costs reduce the amount of debt that students must assume to complete their education. Therefore, the available pool of state aid in the form of subsidized student loans and bursaries goes further, and loan default rates are lower. The state and society benefit in a number of indirect ways as well. More students are able to participate in higher education when overall costs are reduced. Better educational outcomes result when more students are able to afford and therefore actually obtain the texts required for their courses. These desirable outcomes could help equalize worldwide access to education. These large, positive effects for society are the main reason why a growing number of programs funded by governments and private philanthropy seek to identify, evaluate, and fund the development of OER.

There are examples of successful OER project implementation in higher education. The Open Education Consortium at MIT and OpenStax College established by Rice University are wellknown. Daniel (2009) described the creation of a skills-based Virtual University for Small States of the Commonwealth by the Ministers of Education in 32 countries. OER use is a central objective of the project. Funding of a limited number of educational programs is provided by sponsor governments. Stacey (2013) described OER initiatives like the BC Open Textbook Project and the joint J ISC/ Higher Education Academy Open Educational Resources Pilot Program in the UK. Funding of the former has been provided by reassigning existing Ministry of Advanced Education funds. The latter is financed by The Higher Education Funding Council for England.

Butcher and Hoosen (2012) described the government-funded Washington State Board of Community and Technical College's Open Course Library project, launched to develop highquality, low-cost educational materials for over 80 of the state's highest enrolment college courses. Costs of instructional materials to students have been reduced by about $90 \%$ in applicable courses. Estimated savings to students exceeded the costs to produce the first set of courses by US $\$ 1.2$ million. Gourley and Lane (2009) noted that OER were generally embraced by the Open University of the United Kingdom (OUUK) because of the institution's commitment to all facets of open learning. Its OpenLearn project - use of OER within an open Internet-based learning environment - was initiated in 2006. The main reported financial benefit of the project has been additional enrolments in OUUK formal education programs. The related increase in tuition revenue was estimated at $£ 2.7$ million. External grants and internal re-allocation of funding were the principal means of financial support. Friesen (2009) noted that MIT's Open Education Consortium has been managed remarkably well, largely due to management acumen. 
Though it was originally supported by a large external grant, the project's continued success is due to the "enlightened institutional self-interest" of MIT's administration. That is, the project receives institutional support and large amounts of internal funding because it provides significant marketing benefits to MT, particularly the ability to recruit students.

However, Wiley and Gurrell (2009) observed that there is a notable dearth of long-term OER projects, especially among non-elite higher education institutions. Friesen (2009) analyzed life cycles of learning object repositories as proxies for more recent OER initiatives. He noted that all were supported by grants from sponsoring universities, governments, or philanthropic organizations, and that only those that were large, well-funded, and the first of their kind to develop a full range of subject holdings seemed to fare well.

The most significant barriers to increased OER production and use appear to be financial. This is rather curious on the face of it, given that one of their chief hallmarks is that they are free. The issue of course, and as Daniel and Uvalić-Trumbic (2011) noted, is that OER are not "free" per se. The time needed to find and adapt, or produce OER must be taken into account. There may be costs involved to ensure that copyright compliance and legislated accessibility standards are met. Technological infrastructure for production and distribution needs to be supported. An OER initiative may be sustainable for a particular institution to the extent that it attracts new students, facilitates more transparent accountability of taxpayer funds, fulfils its public service role, or advances the institution's reputation, but these are at best uncertain or intangible benefits with limited direct financial reward.

Thus, Wiley and Gurrell (2009) stated that a critical issue for the OER movement is ". . how to provide ongoing, sustainable resources to support a project whose main activity is giving things away ..." (p. 17). Barrett, Grover, J anowski, van Lavierena, Ojoa, and Schmidta (2009) observed that, "No university appears to have found a way of ensuring long-term sustainability [of OER initiatives]" (p. 37). Atkins, Brown, \& Hammond (2007) outlined several major challenges to OER development. Creating a self-sustaining funding model was considered of paramount importance because of the transience of philanthropic and government funding.

This is a common plight of specific OER projects cited in the literature. Keats (2009) described the development of "non-market" educational material at the University of the Western Cape in South Africa. Though concepts of social justice and freedom undergird much of the institution's OER initiative, he noted that actual production and dissemination is slow, mostly due to restricted and unstable funding. Stacey (2013) noted that a US Department of Labor initiative appears to have been stripped of its ability to fund OER development because of the perception that this interferes with commercially-available alternatives. Barrett et al., (2009) noted that lack of sustainable funding impeded efforts of the United Nations University to develop courses and programs based on OpenCourseWare material. They noted that university leaders did not widely support the initiative because of its inability to generate stable revenue streams. Butcher and 
Hoosen (2012) noted that even traditional distance-based universities with their history of developing complete courses have presented little hard data to back up claims for cost savings or efficiencies through the use of OER.

Downes (2007) described nine different funding models for OER projects. Dholakia, King, and Baraniuk (2006) described four. None of these anticipated that a project could eventually generate a self-sustaining revenue stream. Like them, Daniel and Uvalić-Trumbić (2011) concluded that there appear to be only a limited number of feasible alternatives: mainly, governments can provide targeted funds for OER production and use, and educational institutions can encourage inter-institution collaboration and provide incentives for faculty development of OER. Sclater (2010) also observed that to date, direct financial benefits have chiefly been in the form of grants from external bodies, and that arguably, there has been an overreliance on these relatively impermanent sources of revenue. In his analysis of repository failings until 2008, (Friesen, 2009) observed that almost none survived beyond two to three years - the average "sustainability crunch" period for new educational technology projects and, not coincidentally, the usual span of start-up funding. Dholakia, King, and Baraniuk (2006) noted that as is common with the early stages of any innovation cycle, too many OER projects have been started to be financially sustainable. Proponents must consider from the outset how a particular project will continue once start-up funding is exhausted.

Stacey (2010) argued that stable government funding is now needed to enable the disruptive influence of OER to proceed through the inevitable 'valley of death' phase of innovation to a place of financial sustainability. Mulder (2013) also claimed that OER sustainability can only be created by public funding, accompanied by a national educational strategy and a modest reallocation of existing budgets. de Langen (2012) as well argued that, in the final analysis, the only long-term sustainable business model for OER is subsidization by the state. Butcher (2011) implicitly argued the same, suggesting that the educators and educational institutions need to ". . . abandon the pervasive economic logic that education should be treated as a business, governed by the same rules and incentives as the commercial and retail sector" (p. 37).

However, there are issues with these conclusions. Obtaining continued state funding to cover OER production costs by a particular educational institution is tenuous, and requires continued competition for limited government or private philanthropic subsidies. A valid competitive strategy for other institutions that may not be able to trade upon institutional prestige like MIT would be to wait and merely use the OER resources produced by others, much like the early and late majority adopters described by the innovation diffusion model of Rogers (2003). Finally, the state still needs to invest additional funds, or re-deploy scarce resources. It is not clear why it would choose to subsidize OER production and use, rather than employ the same funds in other equally-worthy endeavours. 
de Langen (2013) suggested an "OER-system" - a non-monetary exchange process where reciprocal services would be provided by participants, including production, hosting, cataloguing, quality control, and distribution activities. Still, some cash would be required. He argued that much of this could be provided by the state, which would benefit (rather indirectly, it seems) from quality assurance services that would be provided by such a consortium. However, no practical examples of this approach were cited, and the feasibility of the proposal is questionable for reasons noted above.

Stacey (2010) suggested that cost efficiencies could be realized by limiting aggregation and distribution costs of OER to fewer institutions, and advocated making OER creation and use a normal part of academic institutions' practices. Atkins et al. (2007) suggested similar means, and also suggested a process of transferring course material from formal learning management systems into lower-cost OER repositories, forming membership-based consortia to spread development and distribution costs, establishing wikis to develop and improve OER material, and using social software to capture suggestions by users for improving quality.

In total though, there appear to be few feasible suggestions in the literature about how the use of OER can result in stable, internally-generated net revenue streams for non-elite institutions. This is rather curious, given the vast amounts of money spent on educational material each year and the potential cost savings for students. For instance, Butcher and Hoosen (2012) noted that at the time, the average American undergraduate spent almost US $\$ 1,200$ per year on textbooks and other learning resources.

Perhaps it is only a matter of time before the significant financial benefits of OER overcome these barriers. Allen and Seaman (2014) found that educators perceived little difference in quality between traditional teaching resources and OER. Wiley (2014) argued that the existence of the overwhelming number of "no significant difference" results in comparative media studies over the past decades suggests that, in the absence of persuasive evidence to the contrary, better learning outcomes through the use of commercial textbooks are likely minimal or non-existent. As a result, their significant costs are not warranted. The exclusive, contracted right to publish an author's work is the main value proposition of commercial publishing, not better learning outcomes. Use of OER is therefore a significant threat to commercial publishers. If the benefit to cost ratio (better learning outcomes divided by the cost of purchased material) is considered, improvements to this ratio are much more likely to be achieved by lowering the denominator than by increasing the numerator. This is the chief advantage of OER. To Wiley (2014), the only option is for commercial publishers to produce material which is so highly superior to OER in terms of promoting demonstrably better learning outcomes that the significantly higher price is warranted. This, in his opinion, is unlikely. As a result, he predicts that OER will see a groundswell of adoption in the near future.

This work is licensed under a Creative Commons Attribution 4.0 International License. 
It could be argued that if this observation is correct, why has widespread adoption of OER been so slow to date, after over a decade of development? Both Butcher and Hoosen (2012) and Feldstein (2014) noted that one of the largest obstacles to more widespread use of OER is simply the time needed by faculty to find and evaluate these materials. Feldstein (2014) observed that a large part of commercial publishing revenues support cadres of sales representatives that assist faculty in the learning material selection process. The argument made by Wiley (2014), he opined, did not take into account the need for significant non-production expenditures related to sales and marketing.

But the potential cost savings to higher education institutions should still exceed the marketing costs of commercial publishers, especially if the former's costs are just those needed to free up faculty time to locate OER, and modify the material and teaching practices appropriately. Most higher education institutions charge tuition to students. On initial examination, it appears that an institution could internally reallocate funds to encourage faculty to incorporate OER, create greater cost-savings for students, and market this competitive advantage. Students would be attracted by lower overall educational costs. More should choose the institution, and its enrolments would increase.

However, there are problems with this logic. On the one hand, incentives to increase demand for higher education by lowering costs is not needed in most jurisdictions. The problem is supply. Physical space is limited. The attraction of cost savings, including increased use of OER, are significantly reduced when post-secondary institutions do not have the additional space that would allow more enrolments even if demand increased for whatever reason.

There are other impediments. Christensen and Eyring (2012) studied the barriers to organizational change in the US university sector. They stated that in common with most organizations, universities seek to not only survive but to grow bigger and better at what they do through 'sustaining innovations'. These include more courses and programs, finer buildings, accreditation, and better-qualified faculty. These in turn cause costs to increase. Potential innovations like OER that reduce the costs of education are unlikely to be embraced by existing higher education institutions as they are at odds with this innate tendency to provide increasingly up-scale services. It is true that Christensen and Eyring (2012) proposed a compensating phenomenon similar to the disruptive innovation processes that occur in the private sector (as cited in Christensen \& Raynor, 2003). The emergence of new forms of online learning institutions will increase competitive pressures as these disruptive entrants become accredited and demonstrate value by increasing quality or lowering costs, or both. These new institutions not only attract students that previously could not afford higher education; they begin to draw typical students away from traditional universities as the perceived value of online education increases. The same concept would apply to institutions that adopt OER. 
However, Annand (2006) stated that the effects of disruptive innovation are still muted in most higher education jurisdictions because of inordinate state subsidization of campus-based institutions. For instance, the operating grants on a per-student basis received by campus-based universities in Alberta from the provincial government often exceed those received by its single distance-based university by a ratio of about 2:1 because of the need to support the large physical infrastructure of campus-based institutions. Large capital grants for new campus buildings further increase this discrepancy. Funding post-secondary institutions on a per-enrolment basis without regard to capital requirements would be one means to remove these economic distortions. In effect, additional fees would need to be charged by campus-based institutions to compensate for the costs of providing additional physical facilities, amenities, and services compared to an equivalent online learning program. These increased fees would more adequately reflect the relatively higher costs of a campus-based education. More prospective students would therefore choose online education. On the other hand, current funding practices produce a continuing constraint on the supply of lower-cost online higher education.

OER production and use faces a somewhat analogous problem. A course professor may choose a commercially-produced textbook because it has high-quality production value, instructional aids, or good assessment material. All these reduce the amount of time and effort needed by faculty to prepare and teach, and skew teachers' preferences away from OER. Most higher education institutions also benefit from the use of commercially-produced textbooks. Campus bookstores generally make money. Institutions' costs are also reduced because more faculty time can be assigned for actual teaching, not developing instructional material. Meanwhile, students literally bear the extra cost of this choice, since they must purchase the texts themselves. Allen and Seaman (2014) found that teaching faculty are overwhelmingly responsible for choosing their students' learning materials, but these costs are borne by students at $97 \%$ of surveyed institutions. As well, the lower cost of OER was considered by surveyed faculty to be one of their least important attributes (2.7\% of respondents).Students were not included in the study, so their views on the relative importance of learning material costs were not collected.

However, de los Arcos, Farrow, Perryman, Pitt, and Weller (2014) compiled the results of eight studies with more than 6,000 responses in total from ten countries. Eleven hypotheses were tested through a survey of educators, and formal and informal adult learners. They found that about $80 \%$ of students believe that OER save them money. $56 \%$ of learners but only $38 \%$ of educators believed that use of OER increased student satisfaction. OER were more often perceived as pedagogically equivalent by students. Overall, the results indicated that students are more inclined to use OER than educators because they have different primary motivations than faculty. OER are free and the cost savings overwhelmingly flow directly to students.

However, decision makers' economic interests do not align with those of students. There is a financial disconnect between the course professor(s) or an institutional administrator making the decision to use a particular textbook and the final purchaser of the text - - the student. 
The phenomena of sustaining innovation, lack of competitive pressure, and a financial cost/ benefit mismatch between institutions and their students limits the adoption of OER in most formal higher education settings. A simple expedient would be for governments to require that these institutions use OER. However, this could be perceived as an attempt to limit academic freedom and meet with significant resistance from the academy.

There is a feasible alternative. The state could require that the cost of all instructional materials be included in tuition fees charged to students of higher education institutions. In response to competitive pressures to maintain similar tuition fees, it would be beneficial for these institutions to invest internal funds and institute policies to re-organize teaching activities that encourage development and use of OER. Consider the case of Athabasca University, a Canadian online and distance education provider. Annand (2014) described the production of an OER textbook for use in a high-enrolment course within the Faculty of Business. Several factors converged to make this project financially feasible: a) the availability of a relatively complete, if somewhat dated textbook in digital format that facilitated revision; b) time to update the text within the author's assigned work duties; c) high and increasing costs of competing commercial textbooks; and d) willingness by the copyright holder to allow the revised text to be released under a Creative Commons license. However, the one essential argument that propelled this OER project internally was that financial costs borne by the University were projected to be more than offset by savings. Unusually, all course materials are provided to students by the University, and these costs are included as part of tuition fees. Any cost savings realized through the replacement of purchased textbooks with OER accrue to the institution and thus allow it to limit future tuition increases. Estimated savings in the case of this project are estimated at about $\mathrm{CAD} \$ 75,000$ per three-year revision cycle. The University therefore has a strong economic incentive to use OER, especially within highenrolment courses, and to re-align internal incentives to facilitate their production and use. These same motivations would occur in other higher education institutions if they were required to provide learning materials to students as part of their fees.

\section{Internal Alignment Processes}

The proliferation of state-initiated and funded OER projects is a general recognition that overall cost reductions and other non-economic benefits can be realized by governments and individuals if the production and dissemination of OER can be facilitated in new ways. There are other hopeful signs. In the Allen and Seaman (2014) survey, respondents indicated that the quality of OER was considered equal to or better than that of commercial products across all selection criteria. Hill (2014) also commented that the study indicates there is a philosophical preference for OER once faculty members become more familiar with them. As a result, there is no significant psychological barrier to their use. These tendencies bode well for future adoption of OER, particularly considering that a majority of non-users stated that they would at least consider using OER within three years of the survey date.

This work is licensed under a Creative Commons Attribution 4.0 International License. 
Yet it appears that many of the admirable, top-down government OER initiatives spawned by desires to improve access to education and use taxpayers' monies more efficiently will continue to meet resistance from existing institutions and the professoriate. Despite an admirable amount of altruism in various institutions and individuals that promotes the production and sharing of OER, perhaps the essential lacking feature for widespread adoption is the impetus for universities to change.

Iioshoyi and Kumar (2008) opined that a change in the culture of education is a prerequisite for significant advances in open learning, including the production and dissemination of OER. Barriers of inertia exist in the form of inflexible instructional approaches, unwillingness to view learning as a collaborative student-teacher process, and past investments in technology that constrain future choice. They concluded that institutional resources need to be reallocated to overcome these impediments, as well as creating a mindset of openness, sharing, and collaboration among institutions, administrators, and teachers to make OER understood and welcomed, and their use sustainable. But the question again arises: how can the need for improvements in quality, effectiveness, and pedagogical understanding be effected within higher education institutions? Requiring tuition fees to include the costs of learning materials can be one step. This in turn will encourage an internal realignment of currently-conflicting forces for OER production and use. As de Langen (2013) suggested, a sustainable business model for OER must align overall strategy of an organization with its internal operations. Faculty members, as producers and adopters of OER, must have appropriate incentives. He observed that there can be a potential conflict between individuals and their institutions - for example, when faculty develop materials for personal gain and own the copyright, or when the organization owns copyright and altruistically-motivated faculty do not want to produce OER that will financially benefit the organization. To align incentives for production and use of OER within the educational organization, Sclater (2010) suggested changing tenure and promotion criteria, clarifying ownership of OER, obtaining high levels of commitment from senior managers, developing new models for production and quality assurance, and taking advantage of emerging licensing and distribution regimes. Of particular importance, he argued, was the need to integrate the production of OER fully into the educational processes of the institution, rather than relying on individual faculty members. It is likely, though, that this can only occur with appropriate incentives like release time for faculty to evaluate OER and adapt their teaching practices accordingly. Aligning the financial interests of students and their institutions would encourage these institutions to develop such incentives.

\section{Conclusion}

As Willis (2011) stated, education is both a political and learning process. Critical pedagogy has much to say about inequity, privilege, unequal power structures, and undemocratic processes in our educational systems, and how these might be addressed. Atkins et al. (2007) described a "perfect storm" of factors contributing to the need for sustained funding of OER initiatives: a growing awareness that knowledge is a public good; technology that now allows the discovery, 
sharing and reuse of knowledge on an unprecedented scale; increased governments' commitments to build OER repositories and fund their development, evolution of effective open licensing regimes like Creative Commons, and the growing ubiquity of mobile and "always-on" devices. Perhaps most important, though, is the dearth of institutional capacity to meet the staggering projected worldwide demand for post-secondary education.

In the final analysis, the political means to encourage the supply of lower-cost formal higher education opportunities will be found. The learning needs of a vast sea of individuals require it. Seen in this light, the OER movement does not represent a sufficient change to the organization of higher learning. But it is a necessary one, and the financial means to encourage OER production, dissemination, and use are critical.

\section{References}

Allen, I. \& Seaman, J . (2014). Opening the curriculum: Open educational resources in U.S. higher education, 2014. Report published by Babson Survey Research Group. Retrieved from http:// www.onlinelearningsurvey.com/reports/ openingthecurriculum2014.pdf

Annand, D. (2006). Changing the academy, Staff \& Educational Development International, 10(1), 5-22.

Annand, D.. (2014). Development of an OER financial accounting text at Athabasca University and implications for the broader post-secondary community. Open J ournal of Accounting, 3(4). Retrieved from http:// www.scirp.org/journal/PaperInformation.aspx?PaperID=50329\#.VEUu1_nF9Lo

Armellini, A., \&Nie, M. (2013). Open educational practices for curriculum enhancement. Open Learning, 28(1), 7-20. Retrieved from http:// dx.doi.org/ 10.1080/02680513.2013.796286

Atkins, D., Brown, J., \&Hammond, A. (2007). A review of the open educational resources (OER) movement: Achievement, challenges, and new opportunities. Report to the William and Flora Hewlett Foundation. Retrieved from http:// www.hewlett.org/ uploads/ files/ReviewoftheOERMovement.pdf.

Barrett, B., Grover, V., J anowski T., van Lavierena, H., Ojoa, A. \& Schmidta, P. (2009). Challenges in the adoption and use of OpenCourseWare: Experience of the United Nations University. Open Learning, 24(1), 31-38. Retrieved from http:// www.tandfonline.com/doi/abs/ 10.1080/02680510802627803\#.U7bn1fldU8k 
Bossu, C. \& Tynan, B. (2011). OER: new media on the learning landscape. On the Horizon, (19)4, 259-267. Retrieved from http:// www.emeraldinsight.com/journals.htm?articleid=1953822

Bucher, N. (2011). A basic guide to open educational resources (OER). Commonwealth of Learning: Vancouver. Retrieved from http:// www.col.org/PublicationDocuments/BasicGuide-To-OER.pdf

Butcher, N. \& Hoosen, S. (2012). Exploring the business case for open educational resources. Commonwealth of Learning. Retrieved from http:// www.col.org/ resources/publications/Pages/ detail.aspx?PID=421.

CERI (2007). Giving knowledge for free: The emergence of open educational resources. Center for Educational Research and Innovation. Retrieved from http:// www.oecd.org/ edu/ ceri/38654317.pdf

Christensen, C. \& Eyring, H., (2012). The innovative university: Changing the DNA of higher education. Forum for the Future of Higher Education, Educause. Retrieved from https:// net.educause.edu/ir/ library/ pdf/ff1207s.pdf.

Christensen, C., \& Raynor, M. (2003). The innovator's solution. Boston: Harvard Business School Press.

Daniel, J . (2009).Internationalisation, regionalisation and globalisation: Breaking out of the iron triangle. UNESCO World Conference on Higher Education, Paris, France, 2009. Keynote address. Retrieved from http:/ / www.col.org/resources/ speeches/ 2009presentation/ Pages/ 2009-07$\underline{06 . a s p x}$

Daniel J., \& Uvalić-Trumbić, S. (2011). UNESCO-COL guidelines for open educational resources (OER) in higher education. Retrieved from http:// oerworkshop.weebly.com/ guidelinesfor-oer-in-higher-education.html

de los Arcos, B., Farrow, R., Perryman, L.-A., Pitt, R. \& Weller, M. (2014). OER evidence report 2013-2014. OER Research Hub. Retrieved from http:/ / oerresearchhub.org/ about2/reports/

de Langen, F. (2012). There is no business model for open educational resources: A business model approach. Open Learning, 26(3), 209-222. Retrieved from http:// www.tandfonline.com/ doi/abs/ 10.1080/02680513.2011.611683\#.U7bX0vldU8k. 
de Langen, F. (2013). Strategies for sustainable business models for open educational resources. International Review of Research in Open and Distance Learning, 14(2). Retrieved from http:// www.irrodl.org/ index.php/irrodl/article/view/ 1533/2485

Dholakia, U., King, W., \& Baraniuk, R. (2006). What makes an open education program sustainable? The case of connexions. Connexions cns.org. Retrieved from https:// oerknowledgecloud.org/sites/oerknowledgecloud.org/ files/36781781.pdf.

Downes, S. (2007) Models for sustainable open educational resources. Interdisciplinary J ournal of Knowledge and Learning Objects, 3, 29-44. February 27, 2007. NRC 50353. Retrieved from file:///C:/ Users/ Public.08D011/Downloads/5764249.pdf

Feldstein, M. (2014, Aug 18). OER and the future of knewton. e-Literate. Retrieved from http:// mfeldstein.com/ oer-future-knewton/

Friesen, N. (2009). Open educational resources: New possibilities for change and sustainability. International Review of Research in Open and Distance Education, 10(5). Retrieved from http:// www.irrodl.org/index.php/irrodl/article/ view/ 664

Gourley, B. \& Lane, A. (2009). Re-invigorating openness at The Open University: The role of open educational resources. Open Learning 24(1), 57-65. Retrieved from http:// www.tandfonline.com/ doi/ full/ 10.1080/02680510802627845\#.U7WgLfldU8k

Hill, P. (2014, October 29). Significant milestone: First national study of OER adoption. eLiterate. Retrieved from http:// mfeldstein.com/ significant-milestone-first-nationalstudy-oer-adoption/

ICDE-UNESCO, (2014). Report of the ICDE - UNESCO policy forum. Bali, Indonesia, November 20, 2014. Retrieved from http:// www.icde.org/ ?module=Articles;action=Article.publicShow;ID=5440

Iioshyi, T. \& Kumar, M. (2008). Conclusion. In T. Iioshyi and M. Kumar (eds.) Opening Up Education. Cambridge, MA: MIT Press.

Keats, D. (2009). The road to free and open education resources at the University of the Western Cape: A personal and institutional journey. Open Learning, 24(1). Retrieved from http:// www.tandfonline.com/toc/copl20/24/1\#.UTRywijyQTY

Mtebe, J . \& Raisamo, R. (2014). Investigating perceived barriers to the use of open educational resources in higher education in Tanzania. International Review of Research in Open and Distance Learning, 15(2). Retrieved from http:// www.irrodl.org/index.php/irrodl/article/view/ 1803 
Mulder, F. (2013). The LOGIC of national policies and strategies for open educational resources. International Review of Research in Open and Distance Learning, 14(2). Retrieved from http:// www.irrodl.org/ index.php/irrodl/article/view/ 1536/2505

Okonkwo, C. (2012). A needs assessment of ODL educators to determine their effective use of open educational resources. International Review of Research in Open and Distance Learning, 13(4). Retrieved from http:// www.irrodl.org/index.php/irrodl/article/view/ 1316

Plotkin, H. (2010). Free to learn: An open educational resources policy development guidebook for community college governance officials. San Francisco: Creative Commons. Retrieved from https:// wiki.creativecommons.org/images/6/67/ FreetoLearnGuide.pdf

Rogers, E. M. (2003). Diffusion of innovations (5th ed.). New York, NY: Free Press.

Sclater, N. (2010). The organizational impact of open educational resources. In U.-D. Ehlers \&D. Schneckenberg, (Eds), Changing Cultures in Higher Education: Moving Ahead to Future Learning, pp. 485-497. Berlin: Springer-Verlag GmbH.

Stacey, P. (2010). Foundation funded OER vs. tax payer funded OER - A tale of two mandates. Open Ed Conference 2010 Proceedings, Universitat Oberta de Catalunya. Retrieved from http:// openaccess.uoc.edu/ webapps/ o2/ handle/ 10609/5241

Stacey, P. (2013). Government support for open educational resources: Policy, funding, and strategies. International Review of Research in Open and Distance Learning, 14(2). Retrieved from http:/ / www.irrodl.org/ index.php/irrodl/article/ view/ 1537/ 2481

UNESCO (2012). 2012 Paris OER Declaration. Retrieved from http:// www.unesco.org/ new/ fileadmin/ MULTIMEDIA/HQ/CI/ CI/ pdf/ Events/ English_ Paris_OER_Declaration.pdf

Wiley, D. (2014, August 18). A response to ‘OER and the future of publishing'. Retrieved from http:// opencontent.org/ blog/archives/3462.

Wiley, D. \& Gurrell, S. (2009). A decade of development. Open Learning, 24(1), 11-21. Retrieved from http://www.tandfonline.com/doi/full/ 10.1080/02680510802627746\#.U7R6R_ldU8k

Willis, J . (2011). The cultures of contemporary instructional design scholarship, part two: Developments based on constructivist and critical theory foundations. Educational Technology 51(3), 3-17. 
(C) Annand

\section{Athabasca University}

(c)

